\title{
AGROBIODIVERSITY GENETIC VARIABILITY UTILIZATION IN ORGANIC FOOD PRODUCTION*
}

\author{
Miodrag DIMITRIJEVIĆ ${ }^{\star}$, Sofija PETROVIĆ, Borislav BANJAC, Goran BARAĆ, Velimir \\ MLADENOV ${ }^{1}$
}

\begin{abstract}
Summary The food production at the global level is about to meet its border. Industrialization of agriculture correlates with an explosive enlargement of human population, during $X X$ and at the beginning of XXI centuries. An ongoing process of environmental erosion has been speeding up during that period, not only in our physical surrounding, but also in biodiversity. A new direction in agricultural food production is in demand. Organic food production has been recognized as the way of providing safety and quality food, preserving the environment in the same time. In the other hand new land areas have to be explored for agricultural use, in order to enhance food quantity to meeting the increasing demand for food. These targets set new requirements in plant breeding. To fulfill these requirements the genetic variability harbored in genetic resources has to be preserved, examined and put to good use.
\end{abstract}

Key words: biodiversity, organic, agriculture, genetics, breeding, agriculture

\section{INTRODUCTION}

The human population is growing in a burst. The World entered $20^{\text {th }}$ Century with about 1.5 billion inhabitants, and left it enriched by more than 6 billion. In just 100 years the increment was three time bigger than in all previous human history. At the moment there is more than 7 billion of us, as UN reported, summarized by Roser and OrtizOspina (2017). Further projections are that the mid-estimation of 8.6 billion by 2030, 9.7 billion by 2050, and 11.2 billion by 2100 are to be expected (United Nations, 2015). If Thomas Malthus was right in 1789, theorizing in his Malthusian Theory that the human population growth occurred exponentially, and the food production increased arithmetically, the population would outgrow its resources. Hence, we are heading to our extinction. However, the humanity extinction threat could be overcome by the realistic picture what the future might bring in order to make sound decisions (Bostrom, 2009). The survival of Homo sapiens L., depends on a number of factors. The food security is one of the most important. According to Cribb (2017) "population and economic growth between them will drive a doubling in global food demand by the 2060s", while the humanity is suffering a farmland denudation at the rate of 75 Gigatonnes a year (Wilkinson and McElroy, 2007). However, as Cribb (2017) underlines in a term "The Age of Food", we can prevail by changing farming methods, recycling, preservation, and using "new opportunities in food, such as the 27,000 edible plants on our planet we do not, as yet, eat". Moreover, the humanity is to reconsider its priorities, because we are currently spending 1.8 trillion dollars per year on a new weapons, comparing to 50 billion dollars invested in finding better ways to grow food.

\section{“Norman Borlaug - Humanitarian Hero or Menace to Society”}

In 2014, The Guardian published an intriguing title, cited above, of the John Vidal's article addressing divide opinions on the results of the "father" of Green Revolution World's, famous plant breeder Norman Borlaug, a Nobel Peace Prize winner in 1970. The reason for this divided opinion could be the fact that the World is rapidly heading towards dealing with the consequences of all the accumulated problems in food production over the past 120 years. Up to the beginning of $20^{\text {th }}$ Century, the food production had been the most democratic human activity. Everybody

\footnotetext{
${ }^{1}$ Miodrag Dimitrijević, PhD, professor, Sofija Petrović, PhD, professor, Borislav Banjac, PhD, assistant professor, Goran Barać, $\mathrm{PhD}$, research associate, Velimir Mladenov, MSc, assistant, University of Novi Sad, Faculty of Agriculture, sq. Dositeja Obradovića 8, 21000 Novi Sad, Serbia.

• Corresponding author: phone: e-mail: mishad@polj.uns.ac.rs, phone +381 214853211.
} 
could produce food and trade seed. However, the previous Century was the first one in history to narrowing that freedom. Instinctive breeding has, gradually, been replaced with scientific based breeding programs, that have been carried out by public institutions mostly, until the end of 70's, to be largely privatized in 80's and following decades. The estimation is "that 10 big corporations are controlling almost $50 \%$ of all seeds planted on earth right now (some estimates putting this figure to 73\%, in 2010 up from 37\% in 1995)", according to Lianos et al. (2016). The announcement of the industrialization food production came from pre-WWII Italy. About half of the century before revolutionary changes in primary food production, a plant breeder Nazareno Strampelli started his remarkable career in Italy. His work gave the foundation for the Italian Government set program named "Battaglia del grano" (The Battle for Grain), that started in 1925, till 1940. The aim of the Program was Italian self-sufficiency in bread wheat production (Brandolini and Vaccino, 2012). A desirable genetic variability, Strampelli obtained by crossing, in 1913, a Dutch winter wheat variety from the beginning of the $20^{\text {th }}$ Century, Wilhelmina Tarwe, Italian landrace Rieti, highly prized for strong resistance to stem rust (Puccinia gramminis) a deleterious disease at that time, but highly susceptible to logging, and Japanese semi-dwarf wheat Akakomugi, a $19^{\text {th }}$ Century landrace, carrying Rht 8 gene for stem shortening, to fight logging tendency of tall Rieti and Wilhelmina Tarwe. Obtaining shorter stem, Strampelli successfully overcame logging and dramatically enhanced grain yield of wheat, because the improved plant architecture caused more efficient utilization of assimilative by better translocation of nutrition from vegetative to generative wheat parts. The Ppd-D1 gene, closely linked with Rht8 on 2D wheat chromosome, has been introduced, as well, bringing flowering 8 days earlier. The combination Wilhelmina Tarwe/Rieti//Akakomugi, and the first varieties obtained out of it - Ardito (1916), Villa Glori (1918) were the base for a palette of Italian high-yielding wheat varieties that had been bred in Battaglia del grano. Strampelli's wheat varieties had been extensively grown in many countries after the WWII and served as useful parents in creating novel genetic variability in wheat (Borojević and Borojević, 2005a, Borojević and Borojević, 2005b). However, parallel to this undoubtedly great achievement of genetic plant science and breeding, a question of the connection between plant breeding work, wheat breeding in particular, and the political goals and regimes has been risen (Saraiva, 2010). That connection had been denoted even throughout some of the following wheat breeder's achievements, Norman Borlaug and the Green Revolution, included (Perkins, 1997).

\section{From the Battle to the Revolution}

Stramelli's work in the Battle for Grain, was followed by the work of Norman Borlaug, Iowan wheat breeder, the corner stone person of the Green Revolution that had started after the WWII. The general idea of the Battle and the Revolution was the same - the yield increment. However, the goal was different. While Battaglia del grano was aiming locally, to Italy, the Green Revolution aimed globally, to the World, particularly targeting the World's hunger areas. The Green Revolution relied on the "Borlaug hypothesis" that increasing crop yields could help prevent cropland expansion and deforestation, thus alleviating hunger and poverty without dramatically increasing environmental impact and resulted in controversy (Stevenson et al., 2012; Hertel et al., 2014). Both, the Battle, as well as, the Revolution started in Korea, where short stem wheat landraces were grown in $3^{\text {rd }}$ and $4^{\text {th }}$ Centuries. It is likely that these genetic material was brought to Japan during the Toyotomi Hideyosi's Japanese invasions of Korea from 1592 to 1598. A researcher from Japan, Gondjiro Inazuka, crossed American wheat variety Fultz with short stem Japanese landrace Shiru Daruma in 1917, and Fultz-Daruma progeny with another American variety Turkey Red in 1924, obtaining in 1935 dwarfed variety Norin 10. Inazuka introduced two reduction of height genes $R h t 1+R h t 2$ from landrace parent bringing down wheat plant stature from tall $150 \mathrm{~cm}$, to semi-dwarf of $60-100 \mathrm{~cm}$. Agronomist Samuel Cecil Salmon, served as U.S. Army agricultural consultant in occupied Japan, after WWII. He collected 16 seed samples of Japanese short-sized wheat, Norin 10 included. In 1949, Salmon sent these samples to Orville Vogel, USDA wheat breeder stationed at the Washington State University. Vogel used those samples in crosses to prevail a lodging problem and to release successful commercial varieties. At that time Norman Borlaug was working within The Rockefeller Foundation's Mexican Agricultural Program that started in 1943, by the agreement between Rockefeller Foundation. The aim of the Mexican Agricultural Program (MAP) was to enhance Mexican agriculture and to make it self-sufficient in wheat production. In 1953, Norman Borlaug came into possession of Vogel's semi-dwarf germplasm and began crossing these semi-dwarfs with Mexican varieties, as well as Strampelli's tall variety Mentana, and in a several years the Mexican wheat yield has been doubled. Improved wheat varieties, under the supervision of Norman Borlaug, constituted 90\% of Mexican wheat acreage, by the end of 50's. Borlaug's semi-dwarf set of varieties Pitic, Penjamo, Sonora 64, Lerma Rojo 64, became a starting point of the Green Revolution, at the global level, when wheat varieties from Mexican program were exported to India and Pakistan, in early 60's (Lumpkin, 2015; Umaña, 2016). In 1962, Rockefeller’s MAP, became International Maize and Wheat Improvement Center (CIMMYT). Almost a decade later, Dr. Norman E. Borlaug became a Nobel Peace Prize Laureate for great and go-ahead achievements in increasing food quantity, quality, and availability. 


\section{Life for Erosion - Die Now or be Extinct Later}

The goal of the Green Revolution has been declared as to fighting the hunger in the World. The mean to achieve that goal was by production records Alexey Stakhanov way. The pathway to support that mean was the industrialization of agriculture that is able to pull out the maximum and beyond of plant genetic potentials and land area unit. Consequently, the grain production in India and Pakistan has been doubled on the ground of Borlaug's work. In 1950, the global grain output of 692 million tonnes came from 688 million hectares of cropland for 2.2 billion people. The 2016/2017 the global grain output of 2.5 billion tonnes out of 885.39 million hectares of cropland for 7.5 billion people. That is 3.6 times increase in grain output obtained on 1.3 times cropland area increment at 3.4 times human population growth (Data sources: UN FAO, FAOSTAT). However, could this dramatic increase in plant productivity, be in a consequence of improved plant architecture, only? Is it possible that decrease in height and better sink/source ratio was that influential on grain yield? Some results indicate that the improved sink to source ratio could not be the crucial reason of dramatic yield increment in cereals. Harvest index (HI), that represents the ratio of economic yield to total above ground biomas yield, is commonly used as a parameter to quantify sink to source ratio (Donald, 1962). HI reflects plant efficiency in nutritive matter translocation from vegetative to generative plant part and could be the indicator of productivity, as well as, a selection criterion for increasing yield of cereals (Borojević, 1983). Petrović et al. (2006, 2011) examined plant height and the harvest index of the large sample of wheat (Triticum aestivum ssp. vulgare) consisting of semi dwarf varieties, as well as, tall "pre-revolution" genotypes and some other species of the same genus (Tr. polonicum, Tr. turgidum, Tr. durum, Tr. macha, Tr. dicoccum). According to the results the remarkable advancement in HI, up to $25 \%$, could be observed comparing bread semi dwarf wheat to some of different species within Triticum genus. However, the differences between "prerevolution" varieties and semi dwarf varieties were not that conspicuous (less than 10\%). Moreover, the HI value largely depended on environmental conditions (Dimitrijević et al., 2002). Consequently, shortened plant stature undeniably made certain improvement in sink to source ratio, but more importantly made high industrialization of primary food production possible; hence the real game changer was Agrotechnics. Fertilizers, to the greatest extent. In 1950 farmers applied a bit more than 10 million tonnes of fertilizers (nitrogen, phosphorus, potassium) per year. In 2015 the use of fertilizers was about 180 million tonnes. The key element for the grain yield formation is nitrogen. The application of nitrogen fertilizers grew from 5 million tonnes per year in 1950, to 110 million tonnes per year in 2015 (Data sources: International Fertilizer Industry Association, IFADATA). However, that is not all. The water consumption in agriculture rose from about 1100 cubic km per year in 1950, to $2600 \mathrm{~km}^{3}$ in 2000 (Shiklomanov, 1998). Agriculture uses more than $70 \%$ of extracted water, through the irrigation, mostly (Rosegrant et al., 2009). In addition, the Green Revolution has made primary food production highly dependent on fossil fuel, chemical plant protection, monoculture or nearly monoculture production organization. Consequences of agricultural industrialization are soli degradation, salinization mostly, environmental pollution, biodiversity loss, human diet narrowing, monoculture in food production. Furthermore, narrowing of genetic variability, genetic erosion, and species loss means the erosion of knowledge, as well. Loss of biological resources implies the loss of specific knowledge about them (Mooney, 2001). Moreover, agricultural production industrialization has led to poverty and segregation in agricultural production since the new and more costly technology is affordable to developed countries, and big farmers in developing countries, while small farmers in developing countries suffer further deterioration and differences are deepening. However, agricultural industrialization enhanced food production at a global level, making the food more available and cheaper. Having in mind all that happened in previous century, and the trends at the beginning of this millennium, three processes that are connected to a food production, are ongoing environmental erosion, climate changes and overpopulation. Each of these processes has a great impact on agriculture, and endangers the very existence of human population. All three jointly are more than a threat. It is $H$. sapiens extinction inevitability, and requires quick and serious response (Kopnina and Washington, 2016).

\section{Agriculture at a Crossroads}

Primary food production, at the moment, could be classified in three general groups, according to the production philosophy: 1) Intensive, conventional agriculture - predominant form of primary food production, based on genetic variability obtained in a classic vertical gene transfer way; 2) Intensive, transgenic agriculture - the form of food production rapidly growing from mid-90's, that relies on GMO, novel genetic variability obtained by horizontal gene transfer; 3) Sustainable to organic agriculture - ecologically sound and friendly food production, an integrated farming approach of protecting the environment, public health, human communities, and animal welfare. Intensive, conventional agriculture is at its peak. Something has to be changed qualitatively in order to reach the quantity at the level good enough to establish a balance between satisfying our demands and preserving the environment. The 
direction of further human society organization is going to influence the predominant mode of food production in future. According to contemporary geopolitical movements, two directions of further society development could be projected: Globalization and Souverainism. Intensive transgenic agriculture goes hand to hand with globalization and the corporative World; because transgenic technology deepens further the existing gap between developed countries and the rest of the World. It concentrates the power of food production in hands, of a few mighty corporations. Agriculture based on GMO, as they are today, raises a lot of concerns and questions, and general public rebuffs GM food products al large Worldwide (Dimitrijević and Petrović, 2004, 2005, 2008). Anti-globalism (souverainism) relies on self-dependence, self-sufficiency, trade, traditional contribution of states, nations, regions, according to their mode of production. Sustainable to organic way of primary food production is convenient, not only for big farms, but also for small households, and cooperatives that are predominant owning structure in agriculture in a lot of developing and underdeveloped countries. The United Nations recognizes and reaffirms the role of cooperatives in economic, social and cultural development and in the achievement of social policy (Wanyama, 2014). The role of cooperatives in sustainable development is very important in food production, as well.

\section{Organic Agriculture}

The International Federation of Organic Agricultural Movements (IFOAM) defines organic agriculture as "a whole system approach based upon a set of processes resulting in a sustainable ecosystem, safe food, good nutrition, animal welfare and social justice. Organic production is therefore more than a system of production that excludes certain inputs" (Luttikholt, 2007). Organic farming is a system of agriculture that uses natural and biodegradable inputs while deliberately avoiding the use of synthetic fertilizers and other inputs with adverse effects. As a production system, it is under strict standards and regulation in order to sustain the quality and health of soil, ecosystem and people, relying on ecological processes, biodiversity adapted to local conditions. Organic agriculture combines traditional production methods, innovation and scientific achievements. Although organic farming represents only $1 \%$ of world agricultural area, it is one of the fastest growing sectors of world agriculture (FiBLIFOAM, 2016).

\section{Novel Genetic Variability in Organic Agriculture}

Organic approach requires novel genetic variability, new cultivars that are suitable, by its ideotype, to perform to their best economic result in organic production requirements. According to van Bueren (2002), criteria for organic plant breeding should favor adaptation to low, organic inputs and fluctuating nutrient dynamics, efficiency in capturing and use of water and nutrients, deep intensive root architecture, ability to interact with beneficial soil organisms, weed competiveness in soil coverage and light uptake, durable genetic resistance to pests, field tolerance, maximum utilization of genetic yield potential under low organic input, holding economically sound input/output ratio, and yield stability, high storage potential, and high quality standards of end product. Comparing to Green Revolution (GR) plant ideotype, with a shorter stature, adapted to high input of nitrogen, higher sowing rate and resistant to lodging, organic ideotype is phenotypically closer to more robust and taller pre GR plant stature. For cultivars bred for industrial level of agricultural production, organic growth conditions could be characterized as stressful. Consequently, some of the research experience on growing cultivars under abiotic stress conditions could be of use in creating desirable genetic variability for organic agricultural production.

\section{The sources of useful genes}

In order to broaden genetic variability suitable for meeting the organic food production requirements, available agrobiodiversity is to be screened for usable genes. Biodiversity represents a variety of life types (genetic variation, species variation) on Earth in different ecosystems. Agrobiodiversity is the result of natural selection processes and the careful selection and inventive developments of farmers, herders and fishers over millennia. It includes all components of biological diversity (biodiversity) of relevance to food and agriculture: the variety and variability of plants, animals and micro-organisms at genetic, species and ecosystem level which are necessary to sustain key functions in the agroecosystem, its structures and processes. Agricultural biodiversity or agrobiodiversity is a vital sub-set of biodiversity or the genetic resources for food and agriculture (FAO, 2005). Genetic resources that could be utilized in organic breeding include wild relatives of cultivated organisms, local populations that are well adapted to local environmental conditions due to natural and/or instinctive selection, old varieties commonly obtained in pre GR breeding programs, and even modern GR varieties that could carry some useful genes commonly to meet certain challenges of biotic and/or abiotic stressful growth conditions. Genetic resources harbor useful genetic variability that makes possible the coexistence of different approaches in primary food production, for example, organic and 
intensive or even transgenic fields without contaminating each other, which commonly could be a problem particularly in cross-pollinated cultivars. Demerec (1929), denoted the first case of gametophytic-cross incompatibility in corn. Later on, it was established that cross incompatibility is a single gene Ga1, with multiple alleles controlled, trait (Nelson, 1993). The source of reproductive incompatibility gene system could be found in wild relatives (Fukunaga et al., 2005; Kermicle and Evans, 2010). Breeders are using wild relative genetic resources of gametophytic incompatibility to create novel genetic variability by means of vertical gene transfer by classical hybridization to create "Organic Ready" maize that blocks undesirable pollen contamination, particularly GMO contamination, preserving the purity of organic fields. Organic production, not only preserve the environment, including agricultural land, but also with its sound approach could contribute to the remediation of degraded soil. Salinity represents one of the main forms of soil degradation, mainly by the irrigation that follows intensive, industrial, agriculture. Moreover, there are considerable natural halomorphic soil resources that could be put in a good use in food production. Abiotic stress growth conditions lower yield but enhanced quality. Cereals and other plants interconvert monosaccharides, disaccharides, and more complex carbohydrates such as fructan in order to cope with osmotic stresses, including those caused by salt, freezing, and drought, as well as other stresses such as hypoxia and early senescence (Halford et al., 2015). Salinity increased glutenin macropolyers (GMP) content and large GMP fraction, contributing to better dough quality (Zhang et al., 2016). In order to broaden genetic variability creating wheat cultivars tolerant to salinity abiotic stress growth conditions, breeders are reaching to a gene pool of alien species (Arabidopsis thaliana), as well, as wild relatives (Triticum monococcum), using horizontal, which is not acceptable for organic agriculture, and vertical gene transfer methods to obtain a new gene recombinants (Xue et al., 2004; Munns et al., 2012, respectively).

\section{Creation of Wheat Superior Genetic Variation for growing in Solonetz Soil Conditions}

Solonetz have a base field-pH, and high sodium content. Solonetz occur predominantly in areas with a steppe climate in flat lands with impeded vertical and lateral drainage. Worldwide, Solonetz cover about 135 million hectares, out of which 20 million hectares are in Europe. Major Solonetz areas are in Ukraine, Russia, Kazakhstan, Hungary, Bulgaria, Rumania, China, USA, Canada, South Africa and Australia. In Serbia solonetz occupies about 80000 hectares, mainly in Vojvodina Province, in Banat region. The aim of long-standing research of ours has been to single out a desirable genetic variability in bread wheat, as well as, in situ obtained novel genetic variability, under selection pressure of high sodium content, and overall abiotic stress conditions of solonetz soil. The accumulated results and experience are of use not only for abiotic stress growth conditions of halomorphic soil, but also for organic primary food production, since the solonetz in our experiment was a virgin soil, previously used as a pasture only, with no agricultural intervention, whatsoever. Even, throughout the experiment, the synthetic fertilizers has been applied at the minimum, because of poor funding and other obstacles, providing sustainable and near organic experimental conditions. The multi-year trials have been parallel established in the village of Kumane (45.5219940N, 20.1949190E, altitude 73m, pH = 9.86) on solonetz soil and at the Rimski Šančevi experimental field of the Institute of Field and Vegetable Crops in Novi Sad - IFVCNS - $(45.3249360 \mathrm{~N}, 19.8428830 \mathrm{E}, \mathrm{pH}=6.86)$ on chernozem soil with full intensive agrotechnics. In situ research program was conducted in two phases: 1.) Forming and testing a selected germplasm among the existing genetic variability and 2.) Using selected germplasm as parents in crosses. Since the starting hypothesis was that usable genetic variability could be found among the existing genetic variation of intensive genotypes, a large sample of cereals, wheat mainly, consisting $63 \%$ of locally well adapted varieties from IFVCNS, varieties, about 20\% wheat varieties from the former Small Grains Research Center in Kragujevac has been examined. The rest were local populations of wheat, triticale, barley and some other Triticum species. Among these occasionally tested genotypes, two are of special interest - Old Banatka, as local population obtained by instinctive selection and largely grown in Vojvodina at the beginning of XX Century, and Bankut 1205, tall old bred Hungarian variety that replaced local wheat populations in Vojvodina by the quarter of the previous century (Petrović et al., 2016). Phenotyping represents an important approach in following the variation of plant individual traits, as well as, population reaction of varieties in trial. Outside of intensive, industrial agriculture, individual variation of plants within population gains on its importance in forming final result - grain yield per production surface (Petrović et al., 2012). Deviation of intensive production conditions enhances crossover interaction, as well as, genotype by environment interaction (GEI). Two types of GEI were followed. Stability, characterized by small GEI over environments, and desirable mean value of examined trait, and Plasticity characterized by higher GEI value as a positive genotype response to agro-environmental improvement (soil amelioration, for example). For better understanding of GEI, as well as, for forming primary selection criteria, predominant sources of variation were identified using convenient statistical models. Screening the existing genetic variability relied on top varietal performance that means the highest average of grain yield, and top realization of genetic yield potential, meaning the smallest gap between yield genetic potential estimated by grain yield achieved 
on chernozem soil in an intensive agricultural practice, and realized grain yield on the solonetz soil. Top performance was denoted among the existing intensive varieties, while top realization exhibited mainly landraces (local populations) and old, pre-industrial, wheat varieties, as well as, triticale. The wheat grain yield on solonetz soil, in multi-year trials varied, on average, between 41 and $52 \%$ of the yield on chernozem, using intensive wheat ideotype (Dimitrijević et al., 2011a). The varieties selected were crossed. A novel variation of the existing genetic variability, by was obtained by means of parental gene recombination using classical vertical gene transfer by hybridization. F1 and F2 progenies were obtained, where the mode of inheritance of the grain yield components was investigated. The prevalent mode of inheritance on solonetz soil was super dominancy (positive heterotic effect), hence, selecting desirable genetic variability in novel created variability through years of selection in order to fix super dominancy in homozygosity, could lead to wheat plant ideotype capable to bring forth an economically justified yield, outside of industrial, intensive agricultural practice (Dimitrijević et al., 2012). In addition, an ex situ conservation gene bank has been established, consisting of 200 entries of landraces and wheat wild relatives (Triticum sp., Hordeum sp., Aegilops sp.), as a result of six years collecting expeditions, mainly in Montenegro (Dimitrijević et al., 2011b). Genetic variability study, using protein and molecular markers, is ongoing (Dimitrijević et al., 2017).

\section{CONCLUSION}

Agriculture has undergone significant changes during previous century. The main characteristics of these changes were industrialization of primary food production and seed production concentration in hands of a small number of multinational companies that tend to control the global flow of food. The end of $20^{\text {th }}$ Century brought transgenic technology and genetically modified organisms utilized mostly in a food production. GMOs as they are now, rises a lot of controversy in scientific cycles, as well as, in general public. However, new tendencies in transgenic technology indicate that remarkable changes are on the horizon. Changes that could hit the very core of GMO definition of today. It is likely that contemporary Genetically Modified Organisms (GMO), are going to become Controlled Mutated Organisms (CMO), with very precise induced mutation of genetic material up to the level of point mutations. It seems that the whole technology just might become less exclusive and broader available, as well. However, the serious objection concerning transgenic technology still remains - this technology is lying in the hands of the most developed countries and a handful of mighty transnational companies that are in position to control the food flow at the global level, not only because of GMO, but also because they are holding the vast share of classic seed market. Though Serbian strength in food production has been significantly and deliberately eroded during past 17 years, Serbia is still an agriculturally developed country, with World-recognized classic seed production, good research institutions, high agricultural education and experienced producers hardened in unfavorable production environmental conditions. Serbia is characterized by high biological diversity. Serbia is one of 158 centers of biological diversity with a biodiversity index of 0.718 . Serbia covers only $2.1 \%$ of European territory, but hosts $39 \%$ of European vascular flora, 51\% of European fish fauna, $49 \%$ of European reptile and amphibian fauna, $74 \%$ of European bird fauna, and 67\% of European mammal fauna. There are 3662 plant taxa, 141 families, 766 genera, 3272 species and 390 subspecies in Serbia (MAEP, 2014). Serbia has 5,734.000 ha (0.81ha per capita) of agricultural land, within 4,867.000ha (0.69ha per capita) is arable land. About $90 \%$ of agricultural holdings are small family house holdings up to 10ha (state average is a bit more than 4ha), with 10-20ha owners it rises up to 95\% (SORS, 2013). The structure is very convenient for sustainable and organic agriculture and cooperatives. The Kingdom of Serbia was one of the 12 states founders of International Cooperative Alliance that was founded in London, England on 19 August 1895 during the 1st Alliance Co-operative Congress. In attendance were delegates from co-operatives from Argentina, Australia, Belgium, England, Denmark, France, Germany, Holland, India, Italy, Serbia, Switzerland, and the USA (ICA-COOP, 2017). Serbia has a chance to utilize its resources, accumulated knowledge and experience in food production and combining these with cooperative traditions of its ancestors to organize strong, sustainable to organic high value food production. It is very important to preserve self-sufficiency and independence in food production because an explosive growth of human population that started at the mid- $20^{\text {th }}$ Century is speeding up, followed by environmental erosion and climate changes. The response to these challenges has to be found quickly and sound. The whole human species is facing extinction, and that is not a theory. That is happening as we speak.

\section{ACKNOWLEDGEMENT}

The research presented in this article has been conducted as a part of following research projects: Ministry of Science and Technology Development, MNTR 31066, 2009- ; Series of short term, one year, projects of the Federal Bureau of Plant Genetic Resources, and corresponding Federal and Republican Ministries, during the period from 2001 to 2006. 


\section{REFERENCES}

BOROJEVIĆ S: Genetic changes to increase yield potential in wheat. Proc. 6th Int. Wheat Genetics Simposium, Kyoto, Japan, pp. 953-957. 1983.

BOROJEVIĆ Katarina and BOROJEVIĆ Ksenija: The Transfer and History of “Reduced Height Genes” (Rht) in Wheat from Japan to Europe. Journal of Heredity, 96(4), pp. 455-459, 2005a.

BOROJEVIĆ Katarina and BOROJEVIĆ Ksenija: Historic Role of the Wheat Variety Akakomugi in Southern and Central European Wheat Breeding Programs. Breeding Science, 55, pp. 253-256, 2005b.

BOSTROM Nick: The Future of Humanity. Pub. in New Waves in Philosophy of Technology, eds. Jan-Kyrre Berg Olsen, Evan Selinger, \& Soren Riis (New York: Palgrave McMillan), pp. 1-29, 2009.

BRANDOLINI Andrea and VACCINO Patrizia: A glimpse into the past: Strampelli's bread wheats legacy. Genet. Resour. Crop Evol., 59, pp. 839-850, 2012

CRIBB J: Surviving the $21^{\text {st }}$ Century. Pub. by Springer US and Springer International Publishing AGF, Switzerland, p. $255,2017$. DEMEREC M: Cross incompatibility in maize. Z Indukt Abstamm Vererb 50, pp. 281-291, 1929.

DIMITRIJEVIĆ M, KNEŽEVIĆ D, PETROVIĆ S, ZEČEVIĆ V: Variability and stability of harvest index in wheat. Kragujevac J. Sci., 91-96, 2002.

DIMITRIJEVIĆ, M., PETROVIĆ S: GMO - products of novel technology questions and dilemmas. ESNA European society for new methods in agricultural research, Novi Sad, 29. 08. - 2. 09. 2004. Proceedings 29 - 36, 2004.

DIMITRIJEVIĆ M, PETROVIĆ S: GMO - Evolution Under Control or Frankengene Technology. Contemporary Agriculture, 12, 287-291, 2005.

DIMITRIJEVIĆ, M. and PETROVIĆ S: Genetic modification in function of ecologically justified food or a mortal sin. XII International ECO - conference „Safe food“. 24-27. 09. Novi Sad. Proceedings, 101-108, 2008.

DIMITRIJEVIĆ M, PETROVIĆ S, BELIĆ M, BANJAC B, VUKOSAVLJEV M, MLADENOV N, and HRISTOV N: The Influence of Solonetz Soil Limited Growth Conditions on Bread Wheat Yield. Journal of Agricultural Science and Technology, 5, 2, 194-201, 2011a.

DIMITRIJEVIĆ M, PETROVIĆ S, CÎMPEANU C, BUCUR D and BELIĆ M: Cereals and Aegilops genus biodiversity survey in the west Balkans: Erosion and preservation. Journal of Food, Agriculture \& Environment - JFAE, Vol. 9, Issue 3\&4, pp. 219225, 2011b.

DIMITRIJEVIĆ M, PETROVIĆ S, and BANJAC B: Wheat breeding in abiotic stress conditions of solonetz. Genetika, Vol 44, No. 1, pp. $91-100,2012$.

DIMITRIJEVIĆ M, PETROVIĆ S, BANJAC B, BARAĆ G, YURIEVNA DRAGOVIĆ A., MIHAILOVICH KUDRYAVTSEV A., KNEŽEVIĆ D: Genetic variability of the cereal (Poaceae) germplasm collection monitored by protein and molecular markers. AGROFOR International Journal, Volume 2. Issue No. 1. pp. 75-82, 2017.

DONALD CM: In search of yield. Austr. J. Agric. Res., 28, 171-178, 1962.

FAO: Building on Gender, Agrobiodiversity and Local Knowledge. A Training Manual, 2005. http://www.fao.org/3/a-y5956e.pdf FiBL (Research Institute of Organic Agriculture) and IFOAM - Organics International: The World of Organic Agriculture, Statitics and Emerging Trends 2016. http://orgprints.org/31151/1/willer-lernoud-2016-world-of-organic.pdf

FUKUNAGA K, HILL J, VIGOUROUX Y, MATSUOKA Y, SANCHEZ GJ, LIU K, BUCKLER ES and DOEBLEY J: Genetic Diversity and Population Structure of Teosinte, Genetics 169, pp. 2241-2254, 2005.

HALFORD NG, CURTIS TY, CHEN Z, and HUANG J: Effects of abiotic stress and crop management on cereal grain composition: implications for food quality and safety, Journal of Experimental Botany, Vol. 66, No. 5 pp. 1145-1156, 2015.

HERTEL TW, RAMANKUTTY N, and BALDOSA ULC: Global market integration increases likelihood that a future African Green Revolution could increase crop land use and CO2 emissions. PNAS, vol. 111, no. 38, 13799-13804, 2014.

HILLEL D: Introduction to Environmental Soil Physics. Academic Press, an imprint of Elsevier Science, San Diego, pp. 253, 2004.

ICA COOP: International Cooperative Alliance. History of Alliance. http://ica.coop/en/history-ica [updated June $3^{\text {rd }}$, 2017].

KERMICLE JL and EVANS MMS: The Zea mays Sexual Compatibility Gene ga2: Naturally Occurring Alleles, Their Distribution, and Role in Reproductive Isolation Journal of Heredity 101(6), pp. 737-749, 2010.

KOPNINA H and WASHINGTON H: Discussing why population growth is still ignored or denied, Chinese Journal of Population Resources and Environment, 14:2, pp. 133-143, 2016.

LUMPKIN TA: How a Gene from Japan Revolutionized the World of Wheat: CIMMYT's Quest for Combining Genes to Mitigate Threats to Global Food Security. In: Ogihara Y., Takumi S., Handa H. (eds) Advances in Wheat Genetics: From Genome to Field. Springer, Tokyo, pp 13-19, 2015.

LIANOS I, KATALEVSKY D, IVANOV A: The Global Seed Market, Competition Law and Intellectual Property Rights: Untying the Gordian Knot. Centre for Law, Economics and Society (CLES) Faculty of Laws, UCL London, CLES Research Paper Series, pp 6, 2016.

LUTTIKHOLT LWM: Principles of organic agriculture as formulated by the International Federation of Organic Agriculture Movements. NJAS - Wageningen Journal of Life Sciences, Volume 54, Issue 4, pp. 347-360, 2007.

MALTHUS Thomas: An Essay on the Principle of Population. Printed for J. Johnson, in St. Paul's Church-Yard, London, pp 1126, 1998. 
MAEP - MINISTRY OF AGRICULTURE AND ENVIRONMENTAL PROTECTION REPUBLIC OF SERBIA: The Fifth National Report to the United Nations Convention on Biological Diversity, p. 119, 2014.

MOONEY PR: The ETC Century - Erosion, technological transformation and corporate concentration in the $21^{\text {st }}$ century. Dag Hammarskjöld Foundation, Uppsala, and Rural Advancement Foundation International, Winnipeg, p. 128, 2001.

MUNNS R, JAMES RA, XU B, ATHMAN A, CONN SJ, JORDANS C, BYRT CS, HARE RA, TYERMAN SD, TESTER M, PLETT D \& GILLIHAM M: Wheat grain yield on saline soils is improved by an ancestral $\mathrm{Na}^{+}$transporter gene. Nature Biotechnology, 30, pp. 360-364, 2012.

NELSON OE: The gametophyte factors of maize. In: Freeling M, Walbot V (eds) The maize handbook. Springer, New York, pp 496-503, 1993.

PERKINS JH: Geopolitics and the Green Revolution: Wheat, Genes, and the Cold War. Pub. Oxford University Press, New York and Oxford, p. 337, 1997.

PETROVIĆ S, DIMITRIJEVIĆ M, KRALJEVIĆ-BALALIĆ M, PANKOVIĆ L: Variability and Stability of Stem Height and Harvest Index in Triticum sp. Proceedings of the Research Institute of Field and Vegetable Crops, Novi Sad, Serbia, 42, 237-245, 2006. [original in Serbian, abctract in English]

PETROVIĆ S, DIMITRIJEVIĆ M, BANJAC B, DIMITRIJEVIĆ A: Stability parameters of nutrients translocation in bread wheat. 46th Croatian and 6th International Symposium on Agriculture. Opatija, 14. - 18. February 2011. Proceedings, pp. 417421, 2011. [original in Croatian, abctract in English]

PETROVIĆ S, DIMITRIJEVIĆ M, CÎMPEANU SM, BUCUR D, GURITA AA, HARJA M, MAKSIMOVIĆ L and BELIĆ M: Spike yield stability in wheat grown under stress conditions of alkaline soil. Journal of Food, Agriculture \& Environment JFAE , Vol. 10, Issue 2, pp. 480-464, 2012.

PETROVIĆ S, DIMITRIJEVIĆ M, BANJAC B, MLADENOV V: Selection of wheat superior genetic variation for growing in halomorphic soil conditions. Proceedings VII International Scientific Agriculture Symposium, "Agrosym 2016", 6-9 October 2016, Jahorina, Bosnia and Herzegovina, pp.193-199, 2016.

ROSEGRANT MW, RINGLER C, ZHU T: Water for Agriculture: Maintaining Food Security under Growing Scarcity. Annual Review of Environment and Resources, 34, 205-222, 2009.

ROSER Max and ORTIZ-OSPINA Esteban: 'World Population Growth'. Published online at OurWorldInData.org. Retrieved from: https://ourworldindata.org/world-population-growth/ [Online Resource], updated Jun $2^{\text {nd }}, 2017$.

SARAIVA T: Fascist Labscapes: Geneticists, Wheat, and the Landscapes of Fascism in Italy and Portugal. Historical Studies in the Natural Sciences, vol. 40, no. 4, pp. 457-498, 2010.

SHIKLOMANOV IA: World water resources: a new appraisal and assessment for the 21st century. United Nations Educational, Scientific and Cultural Organization: Paris, pp. 1-37, 1998.

SORS - STATISTICAL OFFICE OF REPUBLIC OF SERBIA: Census of Agriculture 2012. Agriculture in the Republic of Serbia. Book 1, p. 201, 2013.

STEVENSON JR, VILLORIAB N, BYERLEEC D, KELLEYA T, and MAREDIAD M: Green Revolution research saved an estimated 18 to 27 million hectares from being brought into agricultural production. PNAS, vol. 110, no. 21, pp. 8363-8368, 2013.

UMAÑA WP: From Vavilov to Borlaug. Transcontinental Gene Flow and Development of High-Yielding Varieties since World War II. Old and New Worlds: the Global Challenges of Rural History, International Conference, Lisbon, ISCTE-IUL, 2016.

UNITED NATIONS, Department of Economic and Social Affairs, Population Division: World Population Prospects 2015 - Data Booklet (ST/ESA/ SER.A/377), 2015.

van BUEREN TL: Organic Plant Breeding and Propagation. Concepts and Strategies. PhD Thesis Wageningen. Wageningen University and Research Centre, Wageningen, The Netherlands, p. 208, 2002. http://edepot.wur.nl/121365

WANYAMA FO: Cooperatives and the Sustainable Development Goals A contribution to the post-2015 development debate. International Labor Organization. Geneva, pp. 80, 2014

WILKINSON BH and MCELROY J: The impact of humans on continental erosion and sedimentation. Geological Society of America Bulletin, v. 119, no. 1/2; p. 140-156, 2007.

XUE Z-Y, ZHI D-Y, XUE G-P, ZHANG H, ZHAO Y-X, XIA G-M: Enhanced salt tolerance of transgenic wheat (Tritivum aestivum L.) expressing a vacuolar $\mathrm{Na}^{+} / \mathrm{H}^{+}$antiporter gene with improved grain yields in saline soils in the field and a reduced level of leaf $\mathrm{Na}^{+}$. Plant Science, Volume 167, Issue 4, pp. 849-859, 2004.

ZHANG X, SHI Z, TIAN Y, ZHOU Q, CAI J, DAI T, CAO W, PU H, JIANG D: Salt stress increases content and size of glutenin macropolymers in wheat grain. Food Chemistry, Volume 197, Part A, pp. 516-521, 2016.

\section{Received / Primljen: 03.07.2017. Accepted / Prihvaćen: 24.12.2017.}

